\title{
Aspectos Econômicos do Brasil Independente
}

\author{
Professor Mestre Agamêmnom Rocha Souza (Ciências Sociais Aplicadas) - \\ agamemnom.souza@foa.org.br
}

\section{Resumo}

A economia colonial brasileira, que perduraria até a República, de há muito se revelara superior à da Metrópole, mas pelos erros dessa, não conseguira submergir ao fluxo do capital estrangeiro, cuja prioridade, desde a dinastia bragantina, estava com os interesses ingleses, que nunca permitiram a nossa industrialização, e aqui encontraram operoso mercado para seus produtos, de baixo preço, dado às vantagens fiscais e excelente qualidade. $\mathrm{O}$ volume comercial aumentou muito pela mudança de hábitos da população, após a instalação da Corte portuguesa, no Rio de Janeiro. Contribuindo para o nosso atraso, a escravidão, que alimentou uma grande classe rural, porém prejudicou o aperfeiçoamento e desenvolvimento de uma elite comercial somando-se o fato de que os métodos portugueses eram monopolistas de estado, não dando vez à iniciativa particular; por isso o estrangeiro encontrou, no Brasil, campo vasto para expandir seu comércio, em detrimento dos interesses nacionais.

\section{Introdução}

A América Latina, livre da Metrópole, não dispunha daqueles bens que. Em outras partes do mundo, fariam seu povo participante e beneficiário dos frutos do seu trabalho. A sociedade latino-americana compunha-se de duas grandes porções: lavradores e latifundiários, guardando, ainda, resíduos do feudalismo. Esses fatores obrigavam o Continente a submeterse à proteção dos países industrializados, especificamente dos Estados Unidos, cuja prova evidente era a Doutrina Monroe (a América para os americanos). O fenômeno colonial, pois, que continuava a imperar, embora os países nominalmente independentes, afastou a atenção dos economistas, quando estes deveriam dispensar maior atenção. A herança colonial, desta forma, foi uma sociedade sem burguesia e sem proletariado, o que afastava o interesse da filosofia marxista, em que o principal alvo é o Estado capitalista - a luta da burguesia com o proletariado, cujo confronto se avizinhava distante e dependente da transformação da produção que iria criar um proletariado disciplinado e revolucionário. Na concepção marxista, o colonialismo, ajudando a derrubar a estrutura feudal, significa progresso.

A Independência não foi a culminância de um movimento popular, mas de elites, que sempre estão presentes com a missão de dinamizar e pôr no campo prático as idéias, ou mesmo trabalhá-las. No Brasil, a sua missão foi empolgar as lideranças rurais, as mesmas que na América Espanhola se opuseram aos movimentos separatistas da Metrópole, a classe de comerciantes e os meios intelectuais, os quais já vinham se formando desde o século anterior, como se verifica pelos movimentos nativistas. Saliente-se, ainda, que o Brasil, apesar da influência da Corte, sediada no Rio de Janeiro, não assimilara os ideais liberais e libertários porque aquelas elites, que iriam influir na formação dos nossos futuros homens de estado, não tinham sido tocados pelo iluminismo do século XVIII e estavam mergulhados no absolutismo que dominava Portugal. Assim, a Monarquia vinha dentro do próprio processo de Independência, negando os princípios republicanos contidos nos movimentos do século anterior. A dinastia reinante promoveu a separação política sem, contudo, erradicar a pretensão do nosso primeiro imperador de reinar, ou pelo menos influir na Metrópole. Os acontecimentos em Portugal o confirmam. 
A nossa economia há muito ultrapassara a de Portugal, mas continuava, sob certos aspectos, a guardar características coloniais. O retorno da Corte deixou sinais indeléveis nos hábitos da população, agravados pela influência inglesa. Os 15.000 indivíduos que acompanharam Dom João VI, na sua vinda para o Novo Mundo, estavam acostumados a um luxo e a um conforto que a Colônia não dispunha; por isso, os artigos suntuários passam a ser exigidos cada vez mais. A esse fato some-se a população brasileira, que também modificou seus costumes em prol de um padrão de vida elevado. $\mathrm{O}$ aumento das importações, que acabou suplantando as exportações, foi uma conseqüência da demanda desses supérfluos. A estagnação econômica de Portugal, decorrente da ocupação francesa, foi responsável pelas múltiplas concessões à Inglaterra, o que não permitiu um processo de industrialização do Brasil, pelo menos que alimentasse o comércio interno, que sofria desleal concorrência dos artigos ingleses, taxados em quase 50\% menos do que os portugueses, ou mesmo os aqui produzidos. O Brasil entra na era de nação independente, mas dependendo das grandes potências - Inglaterra, França e Estados Unidos.

Mas a atividade produtiva, que tem no trabalho, ajudado pelo capital, sua força econômica ao invés de produtividade agrícola, encontra a mais cara mão-de-obra que é a do escravo, embora aparentemente seja mais barata, isto porque, ele, o escravo, não podendo adquirir bens, não se interessa por nada além daquilo que possa consumir com um mínimo de esforço: qualquer trabalho que ultrapasse a sua necessidade só será conseguido pela violência. Não é admirar que, com tal herança, a escravatura negra. "O Brasil inicia sua vida política independente em um período de recessão econômica, que iniciava alguns anos antes, e que se prolongaria por mais duas décadas”.

O elemento escravo, já referido, predominando numericamente sobre a população branca, também sem acesso a todos os bens, não influiria no consumo, com evidente reflexo indireto na produção, diretamente no comércio e, conseqüentemente, na arrecadação. Como comprova o conceito esmitiano, trabalho e produtividade agrícola não se conciliam. Durante todo o império, os recursos eram canalizados para a lavoura e o tráfico negreiro estava em expansão, apesar da guerra que lhe movia a indústria inglesa, a lavoura cafeeira em ascensão e o capital estrangeiro, entrando na forma de empréstimo, era dirigido ao comércio, dominado pelos ingleses.

A presença de uma classe rural atuante demonstra a inexistência de uma, de comerciantes, que jamais pôde ser estruturada porque a Metrópole impôs sempre o seu monopólio. Em termos reais, o Estado português foi o grande comerciante, sem, contudo descurar a sua participação na indústria açucareira e, depois, maciçamente, na mineração. Essa situação é apontada como um dos fatores responsável pelo atraso do Brasil, no que se refere à sua industrialização, ainda no início do século XIX, e não só aos privilégios concedidos à Inglaterra, como apontam alguns estudiosos. Esse país apenas ocupou os vazios, no organismo nacional, provocados pela política colonial portuguesa. Em tais circunstâncias, deu-se a Independência e foi o predomínio dos "grandes senhores agrícolas" que prevaleceu, a partir de 1831, reconhecendo estes, desde os tempos coloniais, quão prejudicial era depender de Portugal, exigindo liberdade de comércio.

\section{Os Primórdios da Independência}

Em 1814, Dom João VI já deixara claro que a sede da monarquia portuguesa deveria ser no Brasil. Mas a revolução liberal de 1820, no Porto, selou o destino de Lisboa como metrópole do Brasil. A extrema miséria a que estava jogada a velha Lusitânia fez que as Cortes tomassem uma série de medidas, visando à recuperação econômica do Reino, medidas essas, às custas do Brasil. A representação brasileira, em Lisboa, opôs-se a tais soluções, 
porque essas fariam o Brasil retroceder à condição de colônia: o fechamento dos portos e a suspensão do comércio com as demais nações, a justiça e a Fazenda centralizadas em Lisboa, enfim, privando a ex-colônia das principais engrenagens administrativas, além de restabelecer o monopólio de navegação para os navios portugueses, o que significava fretes onerosos.

Desta forma, as relações entre Brasil e Portugal estavam praticamente encerradas, ainda mais depois que a representação brasileira - os nossos deputados perante às Cortes viu-se obrigada a fugir para a Inglaterra. Entretanto, no Brasil não havia partidos políticos para trabalhar as massas. Coube à maçonaria essa missão. As lojas maçônicas não só lutavam pela separação política, como incluíam nessa luta o desenvolvimento do comércio e os incentivos à agricultura, apoio à exploração das riquezas minerais e o estabelecimento de um regime liberal. Fica traçado, assim, o programa econômico-político do regime a ser instalado com a Independência. Com esses princípios, o movimento emancipacionista tomou corpo o empolgou todas as classes sociais. O 7 de Setembro foi o coroamento de todo um processo histórico que veio evoluindo, efetivamente, desde 1808, materializando-se a partir de 1820.

\section{Primeiro Império}

O chamado Primeiro Império compreende duas fases distintas: a de Dom Pedro I, contada de 12 de outubro de 1822 a 7 de abril de 1831, quando abdicou e partiu para Portugal, e das Regências, que se estenderam até o Ato da Maioridade do futuro imperador, a 18 de julho de 1841.

O reinado de Dom Pedro Primeiro foi tumultuado não só nos campos social e político, como no econômico. A primeira luta do Império foi pelo seu reconhecimento. A imprensa da época, composta de pasquins, usava uma linguagem agressiva e pouco cuidada, mas que refletia perfeitamente os anseios populares, ao mesmo tempo em que exaltava os ânimos, que tinham contra os portugueses aqui residentes e donos do comércio, seu grande motivo do Imperador, formado no despotismo da dinastia Bragança, contribuirá para a instabilidade do regime, provocando graves acontecimentos que culminaram com a Abdicação. Entre esses, a dissolução da primeira Assembléia Constituinte e outorga, pelo soberano, de uma Carta Magna. Acrescente-se, ainda, a luta contra as províncias que não queriam reconhecer a autoridade imperial, mantendo-se fiéis a Portugal, o levante separatista da Confederação do Equador e a guerra contra a Argentina pela Cisplatina, que culminou com a independência daquela região, com o nome de República Oriental do Uruguai .

\subsection{Empréstimos Externos}

A economia não gozava de situação melhor do que a política. As dificuldades começaram, de fato, quando o Brasil, para ter a sua Independência reconhecida na Europa, teve que pagar, a título de indenização, dois milhões de libras esterlinas a Portugal, que só assim deu seu beneplácito ao reconhecimento pelas nações européias. O império, além dessa chantagem, assumiu aqui as dívidas portuguesas. Que não eram poucas. A situação tornou-se aflitiva, obrigando o Governo a recorrer a empréstimo na Inglaterra, em 1824. Em 1828, novo crédito bancário foi solicitado - três milhões de libras - a $10 \%$ de juros, que atingiam a quantia de 300 mil libras por ano, incluindo amortizações. No ano seguinte, como a situação não melhorasse, novo empréstimo é conhecido, este, em condições muito desvantajosas e humilhantes por dar como garantia as rendas da alfândega do Rio de Janeiro, ficando esse financiamento conhecido como "o ruinoso", pois das 768 mil libras negociadas, chegaram 400 mil, o restante ficou com os banqueiros, a título de juros antecipados.

\subsection{O Açúcar e o Algodão}


O agravamento da situação econômica não foi só pela guerra no Prata, em 1827, e os levantes internos, mas pela decadência do açúcar e do algodão, que sofriam vertiginosa queda de preços. O açúcar, que dominou nossa economia por três séculos, tinha seu valor reduzido grandemente: de 24 libras-ouro a tonelada, nos anos 1821/1830, caiu para 16,8, no decênio seguinte. Essa crise tivera como embriões métodos de produção que não acompanharam as novas técnicas adotadas nas Antilhas e em Cuba, próximas dos Estados Unidos, grande centro de consumo, e ainda pela concorrência do açúcar de beterraba, descoberto desde Napoleão, cujo cultivo era incentivado em toda a Europa.

O algodão, igualmente, sofria violenta queda de preço. O pluma, na mesma década, de 66,3 libras-ouro a tonelada, baixaria para 47,6. O maior produtor nacional, o Maranhão, viu-se envolvido em intensa crise, em parte, pela revolta da Balaiada, ficando com sua economia estagnada. O problema do algodão se iguala ao do açúcar, quanto à depressão: foram os métodos que não se atualizaram, impossibilitando competir com a vultosa produção americana, que contava com a máquina de descaroçar, recém-inventada, fator que diminuiu o emprego de mão-de-obra, barateando a matéria transformada. O aproveitamento de extensas áreas, praticamente virgens, no sudoeste, colaborava para a estabilidade dos preços, garantindo mercados, tanto internamente, como na Inglaterra, daí a nossa desventura. $\mathrm{O}$ algodão americano, de 80 milhões de toneladas, no princípio do século, subiu para 209 milhões, entre 1821 e 1825, ascendendo a 398 milhões, no qüinqüênio 1831/35. Em libraspeso, o consumo americano passou de 32,5 milhões para 239 milhões, enquanto que, na Inglaterra, a indústria, que consumia 89 milhões, entre 1911 e 1819, atingiu a cifra de 640 milhões, entre 1845 e 1854 . O Brasil não teve condições de participar desse fabuloso volume, pois estava, pelos motivos expostos, alijado de qualquer concorr6encia internacional.

\subsection{Outros Produtos}

A redução de preços não atingiu somente o açúcar e o algodão. Couros e peles, de grande expressão no comércio exterior, representando 74,3\% das exportações, reduziram-se a 52,7\% no decênio 1831/40. Para uma economia dependente exclusivamente da exportação de produtos agropastoris, tais baixas de preços e retração de mercado só poderiam ser catastróficas. Entretanto, surgia uma cultura, que já no tempo de Dom João VI fora estimulada pelo soberano, aparecendo as primeiras plantações nos arredores do Rio de Janeiro, estendendo-se mais tarde pelo Vale do Paraíba, por todo o Estado do Rio, passando a Minas Gerais. Esse produto é o café, que geraria imensas fortunas e dominaria inteiramente a nossa economia.

\subsection{O Malogro do Primeiro Banco Oficial}

O fechamento do Banco do Brasil é uma demonstração do descalabro a que esteve jogada a nossa economia pela administração portuguesa, enquanto aqui se sediou a monarquia. Esconde histórias vergonhosas, também.

Os portugueses de torna viagem despojaram a terra de avultadas somas e, fiéis ao seu sistema de esgotamento até o último momento, esvaziaram todos os cofres públicos, até a caixa das viúvas e órfãos. Só Sua Majestade carregou em ouro em barra e amoedado mais de 60 milhões de cruzados, sem falar nos diamantes empenhados no Banco do Rio de Janeiro a troco de fortes somas e que foram transportadas sem o Banco ser indenizado.

Para cobrir esse verdadeiro desfalque dado ao Banco do Brasil, incumbira o rei a João Rodrigues Pereira de Almeida de negociar, nas praças européias, um empréstimo de 6 milhões 
de cruzados, como parte de outro de 20 milhões, que eram necessários para indenizar o Banco da sangria sofrida.

A situação Calamitosa do Banco do Brasil provocou de Dom Pedro a expressão "banco físico", num expediente enviado ao pai, em Portugal, salientando que a instituição não tinha nem ouro, nem prata e muito menos crédito e dava-lhe quatro meses de vida. O Ministro da Fazenda, Martins Francisco de Andrade, em julho de 1822, dado a falta de numerário, determinou um empréstimo interno de 400 contos, o que foi correspondido pela população, ultrapassando a quantia solicitada, contudo, os problemas não ficaram estacionários.

Após a Independência, o governo devia dez mil contos ao Banco: três mil à firma inglesa Young \& Farnnie e mais de dois mil a particulares. Esses compromissos só poderiam ser atendidos com emissão, uma das funções do estabelecimento, mas o ministro era contrário a essa solução; tomando atitudes drásticas, proibiu a diretoria de qualquer que implicasse emitir.

Visando não só ao Banco, mas ao erário, o Ministro mandou taxar os produtos portugueses em 24\%, equiparando-se às demais importações. Exigiu maior dedicação dos empregados públicos, determinando a demissão dos empregados públicos, determinando a demissão sumária dos relapsos. Outra medida importante foi proibir a eleição para a diretoria do Banco de deputados e acionistas devedores ao estabelecimento. Essas deliberações surtiram os efeitos esperados. Entretanto, as lutas internas, e depois, com a Argentina, constituíram um sumidouro de recursos, agravando as finanças do Império que se via na contingência de emissões e de empréstimos externos, esses agravaram ainda mais a situação financeira. Em conseqüência, o meio circulante, que era de 6.330 contos de réis, antes da Independência, atingiu a quantia de 17.623 contos, em 1830. As emissões, compreendidas entre 1822 e 1832, foram de 760 contos em ouro, 2.830 contos em prata e 13.571 contos em cobre. A inflação estava presente na vida nacional, com uma contínua ascensão de preços dos gêneros em geral, acentuadamente nas cidades populosas, devido a desvalorização do papelmoeda (notas do Banco). As moedas de ouro e de prata foram entesouradas. Isto é, deixaram de circular, cedendo lugar às de cobre, que passaram a ter maior receptividade por ser o único metal em circulação e também mais valorizadas do que o papel, daí sua preferência: uma casaca custava 8 patacas de cobre e 12 em papel; 3 patacas compravam um par de sapatos, que valia 4,5 em papel, e assim, para qualquer mercadoria.

Tal descalabro financeiro e monetário repercutiu na imprensa e passou ao domínio popular, levantando vozes no Parlamento. Os jornais, com suas críticas ferozes, não compreendiam a situação desesperada a que o Banco fora levado pela ação do governo. Em 31 de maio de 1826, foi proposta pela Câmara a formação de uma comissão de quatro deputados para estudar a situação do Banco. O governo foi contra, alegando que o órgão não podia sofrer ingerência em seus negócios, conforme determinava o alvará de criação. A atitude do poder Público foi considerada ambígua porque ele, governo, obrigava o Banco a emitir sem fornecer-lhe recursos. O problema volta a agitar o Legislativo e, em 1827, é o próprio Ministro da Fazenda, em relatório, que apontava as emissões do Banco como causa da situação caótica do país e que o estabelecimento oficial era pessimamente administrado, o que permitiria se transformar numa sucursal do governo. Nova comissão é destacada para estudar a dívida do governo e propor solução. Uma lei, após aprovação, coibindo as emissões, reconheceu e fundou a dívida interna e tentou criar uma Caixa de Amortização para o pagamento das dívidas públicas.

Os problemas econômicos, longe de serem equacionados, se precipitaram vertiginosamente, com o aumento das emissões para cobrir o "déficit” orçamentário, apesar da lei proibitiva. Finalmente, a 23 de setembro de 1829, é aprovada uma lei extinguindo o Banco do Brasil, após longos debates na Câmara e no Senado e ampla divulgação pela 
imprensa. O governo garantiu as notas em circulação emitidas pelo Banco. As Comissões Liquidatárias apresentaram o valor circulante de dezoito mil, novecentos e setenta e quatro contos, novecentos e vinte mil réis (18.974:920\$000), enquanto que a dívida do Tesouro chegava a $18.628 .079 \& 470$.

Todos sentiam a necessidade de um banco, ainda mais porque cerca de 40 casas comerciais do Rio de Janeiro emprestavam dinheiro a juro, para custear a produção. Esse fato levou à criação de uma nova organização bancária em 1838, inteiramente particular e sem a faculdade de emitir.

\section{O Aziago Período Regencial}

Os anos do período regencial foram tormentosos. Como se não bastassem os problemas econômicos e sociais, a instabilidade política estava conduzindo o país para a dissolução. O perigo maior à unidade nacional era a Revolução farroupilha, que se propagaria por dez anos, de 1835 a 1845, e já declarara a sua separação do governo central, com o nome de República Rio-Grandense.

Em quase todos os pontos do território nacional eclodiram lutas populares, sublevações militares, atos de indisciplina. O mais grave, porém, era que todos esses movimentos tinham caráter separatista. Assim foram na Bahia as eclosões de várias revoltas militares, de curta duração, entre 1831 e 1833, todas trazendo no seu bojo a idéia da federação e um acentuado sentimento antilusitano, pretendendo tomar medidas contra os portugueses que se estabeleceram no Brasil. O mais violento desses levantes foi o de negros malês (mulçumanos), de fundo abolicionista, em 1835, em que 1500 dessa crença fizeram derramar muito sangue, até serem contidos. Em Alagoas, na Paraíba, no Rio Grande do Norte, em Pernambuco - Abrilada - Cabanos, no Ceará e no Pará, a Balaiada, em 1839; no Piauí, no Amazonas, no Espírito Santo, em Minas Gerais, aqui, a revolta de 22 de março de 1835 teria como adesistas um grupo que se opunha à proibição de enterros dentro de igrejas, tradição que seria definitivamente encerrada pela República, em 1889, com a secularização dos cemitérios. No Rio de Janeiro, os tumultos e arruaças eram uma constante, provocados pelos grupos rivais - Exaltados e Caramurus ou Restauradores. Na guarnição da capital, minava a indisciplina e, não raro, unidades militares chamadas a manter a ordem, acabavam confraternizando com a turba. Em Santa Catarina, fora proclamada a República Juliana.

Com os vizinhos, os problemas não eram menores: com a Bolívia, em 1838, quase degenera em grave conflito; com a França e Inglaterra, pelas Goianas, em 1827, guerra com a Argentina, já referida; com o Uruguai, pela invasão da nossa faixa de fronteira, que acarretava prejuízos aos fazendeiros gaúchos, obrigou o governo imperial a dispendiosas ações militares. "Não há erro em afirmar que a crise dos últimos anos da Regência foi a pior de toda a história brasileira”.

\section{Segundo Império}

O governo do Segundo Império herdou uma administração que levara o país à beira do caos, com uma economia colonial baseada em antiquados métodos de produção; a primeira preocupação dos novos mandatários foi pacificar a nação, eliminando o último surto revolucionário em São Paulo e Minas, em 1842. A paz, no Sul, só foi atingida em 1845. A economia seria refeita com a prosperidade proporcionada pelo café, que ia criar uma infraestrutura urbana, com fortalecimento político, social e jurídico, de que o Brasil jamais usufruíra, além do progresso geral.

A Revolução Industrial trouxe, fato sobejamente conhecido, substanciais modificações na economia, referentes às manufaturas e às relações sociais, alterando a produção e 
aumentando a variedade de comércio. Cria-se, assim, uma situação anormal que vem influir na transformação das idéias. Esse progresso econômico foi vertiginoso e a Inglaterra ingressa no século XIX com uma "combinação de circunstâncias excepcionalmente favoráveis para o florescimento de uma sociedade capitalista". A rapidez da máquina aumentava a produtividade do trabalho e a acumulação e os investimentos de capital atingiram níveis elevados, com que no século anterior não teriam sido nem sonhados, pela estreiteza do mercado de trabalho, devido, principalmente, ao capitalismo inglês.

O império submete-se a tão poderosa economia, a inglesa, que já nessa época aflora, além das classes privilegiadas e dominadoras, o Grupo de Pressão, "fenômeno próprio de economia desenvolvidas", no caso, a inglesa e tornar-se-ia uma constante, na economia brasileira. O Visconde do Mauá, Irineu Evangelista de Souza, foi o mais atuante e eficaz agente do capitalismo inglês, no Império do Brasil, sendo fundador de grandes empreendimentos: a navegação no amazonas, o Banco Mauá, a Companhia de Gás - por trás dos quais estava Rothschild. O Banco Mauá esterlina que sustentou, com vultosos empréstimos ao Brasil, a Guerra do Paraguai, cujo ouro ficou todo na Argentina, território através do qual partiram todas as operações brasileiras, contra Solano López, contrariando os planos apresentados por Caxias, que previam as ações por Mato Grosso, tendo São Paulo como ponto de concentração.

A estrutura agrária chega ao $2^{\circ}$. Império apresentando fortes tintas coloniais, pois a economia estava assentada no latifúndio, fator que jamais permitiria a formação de empresas capitalistas modernas, com base tecnológica, como nos países que atingiram o desenvolvimento. Desta forma, não foi possível o surgimento de empresários e administradores que proporcionassem ao Império um poder econômico e político saliente e perene. Com seu desenvolvimento dependente da agricultura, em mãos de uma oligarquia agrário-comercial, emprega processos capitalistas para exportar, mas internamente, guarda processos capitalistas para exportar, mas internamente, guarda um caráter semifeudal, pois reflete, ainda, o sistema econômico da metrópole decadente, permanecendo mercantilista, indiferente ao fator principal, que é a produção qualitativa, e não quantitativa; daí a especulação, ao invés da eficiência produtiva.

\subsection{O Café}

O que seria a maior força econômica do Brasil começou modestamente na zona urbana da cidade do Rio de Janeiro, trazido do Maranhão, num sítio dos padres capuchinhos, na atual rua Evaristo da Veiga, de onde passou aos arredores. No ocaso do século SVIII, já era cultivado nas chácaras da Tijuca à Baixada de Jacarepaguá. De cultivo doméstico, raro era a família que não tivesse seu arbusto, colhendo os frutos, torrando-os e moendo-os para consumo próprio. A sua trajetória comercial iniciaria, pelo vale do Paraíba, já no primeiro quartel do século XIX, alastrando-se por toda a província fluminense, ocupando as antigas sesmarias, guardando as mesmas características dos latifúndios açucareiros, que fizeram a grandeza do Nordeste por três séculos.

Dom João VI não incentivou a cultura do café, como fez doações de terras a muitos nobres entre os que o acompanharam na vinda para a Colônia da América. Em 1818, havia, na região de Resende e de São João Marcos, cerca de 20 mil pés de cafeeiro. A demanda mundial tem seu marco em 1820, quando os preços sobrem bruscamente e a lavoura recebe grande incremento, aumento a exportação. O número de estabelecimento vai crescendo em direção a São Paulo e em 1837, só na região de Areias, contam-se 238 fazendas e, em Bananal, 82. A exportação de café nesse ano suplanta a do açúcar, representando mais da metade do total de toda a exportação brasileira, ultrapassando um milhão de sacas e penetrando nos principais centros do mundo. 
O café, crescendo em prestígio, eleva a economia e surgem os primeiros bancos particulares: no Ceará, em 1836; no Rio de Janeiro, em 1838; em 1846, no Maranhão e em 1947, na Bahia e no Pará. O mais importante desses órgãos creditícios foi o Banco Mauá, fundado na Corte, em 1851, porque em 1853 passaria à condição de banco emissor. O surto econômico criado pelo café deu condições para uma série de melhoramentos: a iluminação a gás, no Rio de Janeiro, o telégrafo e a navegação a vapor, no Amazonas, em 1854, é inaugurada a Estrada de Ferro Mauá.

A decadência da cultura cafeeira, nas imediações da capital do Império, em 1859, coincide com a produção mineira, contribuindo com 8\%; com a de São Paulo, $12 \%$ e a da Província do Rio de Janeiro, com 78\%. Calcula-se em 600 o número de fazendas só no Vale do Paraíba - da antiga região pioneira de Resende e São João Marcos até o norte fluminense, algumas com grande capacidade produtiva, como as da família Breves, em Piraí, produzindo 90 mil arrobas, e outras com uma produção de 60 e 50 mil arrobas, por safra. Outro mérito atribuído ao café foi o de ter aberto o mercado americano, fazendo seu povo substituir o hábito do chá pelo produto brasileiro.

O aumento da produção acompanhou a ascensão dos preços, com um declínio na última década da monarquia:

\begin{tabular}{|lll|}
\hline DECÊNIOS & PRODUÇÃO (Sacas 60 kg) & PREÇOS (libras) \\
\hline $1841-1850$ & 17.121 & 1,32 \\
\hline $1851-1860$ & 26.253 & 1,89 \\
\hline $1861-1870$ & 28.847 & 2,36 \\
\hline $1871-1880$ & 36.336 & 3,11 \\
\hline $1881-1890$ & 53.326 & 2,54 \\
\hline
\end{tabular}

A exportação do café reduziu a dos demais produtos. O açúcar, com uma participação de $28,5 \%$ no comércio exterior, em 1840, baixou para 6,2\%, em 1890; o algodão, de 9,4\% para 2,4\%; o couro decresceu em 3,6\%. Outros produtos, porém, aumentaram as vendas: o fumo, $1,6 \%$ para $2,1 \%$; a borracha, de $0,5 \%$ para $9,7 \%$ e o mate, de $0,7 \%$ para $1,5 \%$. O cacau manteve-se estável.

O plantio e comercialização do café era fator de desenvolvimento para as regiões, proporcionando construções de ferrovias e aparelhamento dos portos, que trazia progresso também para outros setores, como comprova o aumento dos rendimentos públicos, nas províncias cafeeiras:

\begin{tabular}{|lll|}
\hline PROVÍNCIAS & 1849 & 1889 \\
\hline Ro de Janeiro & $885: 100 \$ 000$ & $4.399: 250 \$ 000$ \\
\hline Bahia & $868: 042 \$ 000$ & $3.345: 101 \$ 000$ \\
\hline Pernambuco & $714.346 \$ 000$ & $3.577: 870 \$ 000$ \\
\hline Minas Gerais & $444.027 \$ 000$ & $3.474: 000 \$ 000$ \\
\hline São Paulo & $290: 848 \$ 000$ & $4.089: 318 \$ 000$ \\
\hline
\end{tabular}

\subsection{O Trabalho Escravo pelo Escravo Assalariado}

A modernização dos processos de produção vai permitir o desenvolvimento políticoeconômico. Compreende-se, pois, que o desenvolvimento é o “output”, que exige todo um processo evolutivo denominado de modernização. Com cujo contato as técnicas arcaicas são substituídas. 
Das muitas vozes que se levantaram no Parlamento sobre o trabalho servil, estava a do Senador Vergueiro (Nicolau de campos Vergueiro), que defendia a substituição gradual do negro imigrante europeu. Por sua iniciativa, introduz, em 1840, os primeiros colonos portugueses e, em 1947, suíços, para trabalharem em sua fazenda de Ibicaba. Várias medidas foram propostas visando a abolir a escravidão, sendo que a maioria não foi aprovada. $\mathrm{O}$ primeiro projeto de lei foi do José Bonifácio, em 1822, em que dava prazo de cinco anos para a suspensão do tráfico negreiro, direito ao próprio negro de se alforriar, indenizando o senhor; proibia a venda em separado do marido, mulher e filhos, além de outras medidas. Quatro projetos movimentaram a Câmara, de autoria do médico e deputado pela Bahia, Antônio Ferreira França, em 1830, 1831, 1833 e 1837, pelos quais tentava o ventre-livre, só aprovado em 1871, no Ministério Rio Branco. Em parte, as autoridades do Império tinham razão, como tivera Pedro I, favorável à extinção do trabalho servil, porque uma ação precipitava em total dependência do escravo. A abolição deveria ser lenta, para permitir a formação de uma nova base obreira assalariada, sem causar solução de continuidade.

A escravatura no Brasil era mantida pelo tráfico, de tal forma intenso, que alimentava aqui imensas fortunas, sendo os negociantes mais prósperos aqueles que se dedicavam ao nefando comércio, que incluía pessoas de alta projeção social, tanto da nobreza como fazendeiros de café. Entretanto, a Europa passava por profundas transformações com a chamada Revolução Industrial, que trazia a estruturação definitiva do capitalismo. Os novos grupos industriais, principalmente, ingleses, tinham grande interesse em ampliar os mercados para a colocação de seus produtos, que sofriam concorrências daqueles, de procedência das colônias americanas, com preços bem mais baixos, dado os mínimos custos conseqüentes do braço escravo.

A Inglaterra inicia intensa campanha com a intenção de acabar com a escravidão, aumentando seus mercados - no campo diplomático, alimentando associações filantrópicas que combatiam o cativeiro ou em congressos internacionais. Na América espanhola, principalmente nas Antilhas, teve sucesso, o mesmo não acontecendo com o Brasil. Numa das cláusulas do reconhecimento da nossa Independência, pelos ingleses, em 1826, constava que o tráfico deveria ser suprimido até 1830. Tal não se deu, apesar de que em 1831 foi baixada lei proibindo. A lavoura cafeeira crescia vertiginosamente e a demanda de braços não tinha limites, o que tornou essa lei letra morta. Os ingleses recorreram à inspeção e apreensão em alto-mar dos navios brasileiros, baseados no "Bill” (lei) Aberdeen, de 1845.

Ao mesmo tempo em que aumentam nossos protestos diplomáticos, recrudescem os atos atentatórios à nossa soberania, chegando a abusos de inspeções a navios ancorados em portos de território nacional e, muitas vezes, em alto-mar, não sendo encontrada a carga, via de regra, valiosa, de porcelana, prataria, objetos de arte, tecidos finos, jóias, etc. Paradoxalmente, o tráfico intensificou-se e, também, os riscos, o que fez crescer o preço do africano, de 630 mil-réis para 1:350\$000 (um conto, trezentos e cinqüenta mil-réis), e o número de "peças" que era de 17.000 a 22.000 por ano, pulou para 60.000, em 1846. O governo brasileiro é obrigado a ceder e, em 1850, a Lei Eusébio de Queiroz aboliu o tráfico negreiro.

As fazendas de café são os primeiros elementos a se ressentirem com a medida, justamente no momento em que maior era a produção e também sua contribuição para a economia do Império. Para compensar a falta do negro, os "barões do café” passam a transferir o excesso do Nordeste, dado a decadência do açúcar, para as províncias cafeeiras. Em oito anos, de 1852 a 1859, cerca de 26 mil são deslocados para o Vale do Paraíba.

A produção no Oeste paulista ganhava proporções e se ressentia de trabalhadores. Por isso, em 1848, a Comissão de Indústria e Comércio da Assembléia, na Província de São Paulo, sugeriu ao governo que autorizasse o transporte de trabalhadores e em 1852 era votada uma verba de 25 contos anuais destinados à colonização. São dados, assim, com o Senador 
Vergueiro e essa decisão da Assembléia paulista, os primeiros passos indicando a transição dôo trabalho servil para o salariado. Começa a vigorar o regime de parceria, que é a obrigatoriedade do colono de cuidar de determinado número de pés de café, com a participação nas vendas: é-lhe facultado, também, plantar víveres nos interstícios do cafezal, cujo produto é repartido com o fazendeiro. Esse regime fracassou porque os atritos e demandas judiciais foram inevitáveis, havendo interferência diplomática por parte dos países de origem dos colonos, além de uma campanha no exterior contra a emigração para o Brasil. O regime de pagamento também não satisfez, dado os baixos salários, que não estimulavam o imigrante, que só pensava em enriquecer ou, pelo menos, tornar-se independente. Problemas como esse de São Paulo foram iguais em Minas Gerias e Rio de Janeiro.

Caberia ainda a São Paulo outra primazia: a melhoria dos antigos métodos de preparação do produto para mercado. De uma operação manual, com varas batendo nos cocos para descasca-los, para o primitivo monjolo e, depois, o carretão tirado a bois que evoluiu para o pilão movido por um moinho de água. Essa modesta aparelhagem é preparada na própria fazenda com a madeira colhida em suas matas. A modernização de todo o sistema chega pouco depois, em forma de máquinas de metal, adquiridas nos Estados Unidos ou Europa, que põe a fazenda em contato com o estrangeiro e deixa para trás as antigas do território fluminense. Já em 1886, há em Campinas 20 máquinas Conrado e 33 da marca Lidgerwood; destas, 11 eram acionadas a vapor e 22, por força hidráulica. Esse fator foi também preponderante para a introdução do trabalho livre no que foi a maior força econômica do Brasil - a lavoura cafeeira.

No Nordeste, a introdução da máquina foi mais lenta. Os novos métodos no fabrico do açúcar, ocasionando maior racionalização das atividades, favoreceu a transformação do trabalho escravo para o trabalho livre, criando uma cisão entre a lavoura de cana-de-açúcar, que incluía o senhor de engenho, e o novo industrial - o usineiro - porque entre ambos estavam as novas técnicas, separando o antigo regime patriarcal e o empresarial, aquele agarrado à servidão e esse devoto do trabalho livre. Daí a permanência de um sistema agrário latifundiário e com características feudais que haveriam de permanecer, na zona canavieira, em grande parte, até nossos dias. Na região Sul, todo foi diferente. Lá a pecuária se destinava ao mercado nacional, ao contrário das monoculturas do Centro-Oeste e do Nordeste, que tinham seus produtos condicionados às oscilações do mercado internacional, para onde se destinava sua produção - açúcar, algodão e café. Desde os tempos coloniais, as lides nas est6ancias dispensavam numerosa mão-de-obra e grandes extensões de terra, o que eliminava aquilo que o açúcar, e depois o café, passou a exigir - o latifúndio e uma multidão de escravos. Na verdade, as províncias meridionais tinham pouco contato com o centro e sua preocupação maior era com os vizinhos castelhanos, que queriam arrebatar-lhes as terras e criações, o que levou o Império a manter-se sempre em guarda, com grandes despesas militares.

Esta passagem do trabalho servil para o trabalho livre, /.../ teve um relevo muito saliente para a nossa economia, porque com ele teve início a introdução e o desenvolvimento do capitalismo entre nós, pois, até aí, nossa paisagem econômica, social e política era a que vinha do tempo colonial.

\subsection{O Capital Estrangeiro}

Sem dúvida, o $2^{\circ}$. Reinado ofereceu ao Brasil expressivo desenvolvimento representado pelo surto econômico do café, pela introdução de colonos estrangeiros, pelas leis referentes à escravidão, culminando com a Abolição e a queda da monarquia, pela substituição do trabalho escravo pelo assalariado, pelo aumento da população, que propiciou 
maior demanda de bens, com o desenvolvimento da indústria e do comércio e uma maior oferta de trabalho, com a melhoria de vida das cidades pela iluminação a gás, transportes urbanos e abastecimento de água; construção de ferrovias, navegação a vapor e a comunicação com as províncias pelo telégrafo, além do aparelhamento das Forças Armadas para enfrentar a invasão paraguaia. Foram, assim, criadas condições para que grandes capitais estrangeiros fossem para cá transferidos, predominantemente ingleses, que já vinham se avolumando desde 1810, mas que a partir da metade do século tomara enorme vulto, nas mais variadas atividades, notadamente no setor público, com a concessão de ferro - São Paulo e Leopoldina Railway, esta atendendo aos subúrbios cariocas, como transporte de massa, bem como para carga e passageiros, nas Províncias do Rio de Janeiro e Minas; no Nordeste, a Great Western; bancos, usinas de açúcar e mineração, enfim, o capital inglês era senhor absoluto.

Com o advento da eletricidade, as centrais elétricas e a exploração da distribuição de energia caíram no seu domínio e também os serviços telefônicos. O mais grave de toda essa situação era a execução dos serviços concedidos: o material, engenheiros e técnicos vinham da metrópole, o que quadruplicava os custos, se forem considerados os gastos com esse pessoal para a montagem e manutenção de qualquer empreendimento. A navegação de longo curso era monopólio inglês, que incluía o seguro, também feito em companhia inglesa. $\mathrm{O}$ comércio inteiro, já referido, era predominante estrangeiro: os ingleses, com as casas atacadistas de fazendas, louças, ferragens, etc; os franceses vendiam artigos finos femininos, jóias, calçados, etc; os portugueses, o comércio miúdo, como hoje - açougue, padarias, quitandas e armazéns. Nos demais centros - São Paulo, Recife, Bahia e outros - o quadro era idêntico, guardando as proporções.

O domínio da economia pela Inglaterra encontra amparo no fato de que, a partir do século XVIII, ela canalizou seus interesses numa série de invenções e soube aproveita-las da melhor maneira: a máquina a vapor que usou nos processos de tecelagem, antes já empregara a lançadeira volante; a máquina de fiar hidráulica, do filatório e do tear mecânico. Evidentemente, esse conjunto de criações foi um poderoso instrumento para o enriquecimento, destinado à vestimenta, constituindo, como ainda hoje, um imperativo de consumo, tanto para a ostentação dos ricos, como necessidade indispensável aos pobres. As máquinas, transformando o artesanato caseiro em indústria, levaram a confecção para a tecelagem. Até então, "toda a economia era uma economia agrícola" que o advento da Revolução Industrial conduziu ao pensamento econômico, nascendo um espírito generalizado de mudança técnica com aumento da confiança e orgulho nos resultados obtidos.

Não foi outro o instinto que animou os ingleses ao dominar a nossa economia, despejando aqui sua produção industrial e o seu excesso de dinheiro nascido dessa mesma máquina e que estava em plena expansão, dominando o comércio internacional e, particularmente, o da América do Sul. O aspecto, porém, mais pernicioso da ação inglesa no Brasil é aquele referente aos empréstimos. Grande parte desses se destinava a financiar obras públicas, como ferrovias e usinas centrais, por exemplo, cuja concessão seria dada aos próprios financiadores. O governo recorria a créditos dos bancos ingleses para comprar material na Inglaterra e pagar o pessoal de sua própria nacionalidade que viesse trabalhar aqui. As companhias formadas no Brasil tinham como acionistas as empresas que forneciam os fundos, com rendimentos bem elevados e ainda os juros sobre o capital concedido. Em tais condições, o Império exercia grande fascínio aos órgãos de crédito. Em 1855, firmamos contrato com a Casa Rothschild (N.M Rothschild \& Filhos), nomeando-a nosso agente financeiro, o que lhes garantia exclusividade para receber quaisquer fundos em letras, ouro em barras ou em pó, diamantes, dinheiro ou mercadoria destinados a pagar nossas contas dividendos, salários, empréstimos, etc. Sobre qualquer operação, a Casa recebia 1\%, 1,4\% sobre empréstimo contraído em outro estabelecimento, se com a Casa Rothschild, 1\%. Essas 
percentagens eram independentes das taxas de corretagem, o que aumentava grandemente os emolumentos. É evidente que esse contrato não atendia os nossos interesses. A sua validade seria até 1858, mas continuou vigorando porque o governo brasileiro não saldou seus compromissos, condição exigida pelos credores.

No reinado de Dom Pedro II, os gastos militares se constituíram no grande sumidouro de dinheiro. A Revolução Farroupilha, que se prolongou por dez anos; as interferências; porém, o maior conflito, que exauriu a nação, foi com o Paraguai. A dívida externa subiu a 989 mil contos, só com a Casa Rothschild, o que a República desmentiu, afirmando ser de um milhão e 79 mil contos de réis, Rui Barbosa, Ministro da Fazenda do primeiro governo republicano, afirmou que "o Império era o déficit”. Ouro Preto, o último primeiro ministro imperial, contestou afirmando que $67 \%$ dos empresários se destinaram a custear as secas no Nordeste de 77/78, em que morreram 200 mil pessoas; aquisição da estrada União-Indústria; em ferrovias, em epidemias e em gastos extraordinários.

O mais oneroso não eram os juros (4 a 5\%), mas a comissão percentual sobre o total de cada operação, entre 16 e 5\%, conforme o caráter da transação, e mais as comissões pagas aos intermediários. Assim, grandes quantias ficavam na origem: em 1875, de L5.301.200, apenas 5 milhões chegaram ao Brasil; de L 4.599.000, em 1883, 4 milhões líquidos foram entregues. Como se não bastassem nossos próprios problemas, éramos onerados ainda com as antigas dívidas portuguesas, que tivemos que assumir para que Portugal reconhecesse a nossa Independência, além dos dois milhões de esterlinos pagos a título de indenização, já citado. De 1843 a 1889, os empréstimos, em número de treze, atingiram a soma de L61.896.3000.

\subsection{Crises Econômicas}

As constantes pressões da Inglaterra sobre o tráfico negreiro obrigou a aprovação de várias leis visando a abolir, aos poucos, a escravidão, repercutindo na produção. $\mathrm{O}$ crescimento da força de trabalho não encontrava na imigração o número suficiente de braços que substituíssem, principalmente, na agricultura, o escravo. Nas cidades, nas profissões que demandassem especialização, pois o ensino profissional era olhado como uma espécie de desonra, próprio para os miseráveis, aqueles desvalidos criados em asilos. Assim, a imigração européia deparou aqui com obstáculos característicos de regime escravista, o que causava mal estar, como trabalhar ao lado de escravos. A repercussão se fez sentir na Europa e, em 1859, o governo alemão proibiu a vinda de seus colonos e artifícios, tão bem inaugurada em 1824, com a instalação da primeira leva, à margem do rio dos Sinos, criando a cidade de São Leopoldo, no Rio Grande do Sul e, mais tarde, Novo Hamburgo, que tomaram grande importância pelo desenvolvimento industrial - a primeira, com artefatos metálicos e a outra, curtume e fabricação de calçados. Mas as correntes imigratórias se sucediam dado a necessidade de reposição de mão-de-obra, aumentando sempre, localizando-se mais nas províncias do Sul.

A carência de trabalhadores não foi uma crise tão profunda, que abalasse nossa economia. O Brasil nasceu como mero fornecedor de matéria-prima, e foi com essa condição que se inseriu no quadro mundial. Lógico que sentíssemos todos os reflexos das principais mercados e também fornecedores. A fragilidade mais visível era a dependência das exportações a um único produto - o café. Os demais reunidos não chegavam à metade desse, que possuía caráter secundário no mercado mundial. Em 1857, um forte abalo atingiu as exportações brasileiras, causando um prejuízo de 15 mil contos, provocando 49 falências; em 1858, nova e grave crise, com 90 falências; a mais terrível, porém, foi a de 1864, com perdas avaliadas em 65.000 a 70.000 contos, com centenas de falências em todo o país. Some-se, ainda, que os constantes empréstimos contraídos no exterior nos obrigavam a um crônico balanço de pagamentos desfavorável - maiores despesas do que receita - isto sangrou as 
finanças do Império em 224 mil contos, entre 1853 e 1862. O problema aflorará em sua correta dimensão, se o compararmos com o "superávit" de nossa balança comercial, nos 48 anos de monarquia, que foi de 89.808 contos. Era inevitável que a situação externa se refletiria no orçamento, também sempre deficitário, daí a ininterrupta busca de créditos externos e a conseqüente dependência política internacional.

Dessa situação, decorria a constante evasão de moedas metálicas, obrigando a emissão de papel-moeda (fiduciária) para cumprir compromissos internos, o que, para muitos, seria um gerador de crises, dado o abuso dessas emissões, permitidas a bancos emissores, nas Províncias. Para outros, essas emissões eram necessárias para suprir a carência de numerário nas praças, principalmente depois de 1850, com o surto comercial e industrial que se verificou.

Portanto, os emissionistas, entre esses, Mauá, tinham defensores e atestavam que o meio circulante era um efeito, e não a causa, que seria algo mais profundo e carente de estudos e soluções. Essa imitação do liberalismo econômico praticado na Europa era condenada por Ouro Preto, Presidente do Conselho de Ministros do último Gabinete Imperial, que defendia o sistema protecionista praticado pelos Estados Unidos da América, que fez a grandeza daquele país, enquanto o Império continuava mergulhado em crises cíclicas, das quais até nossos dias o Brasil não conseguiu emergir.

\subsection{Industrialização}

Há mais de cem anos que a Inglaterra gozava de privilégios, no Brasil. O Tratado de Methwen, assinado em Lisboa, entre Portugal e Grã-Bretanha, esta representada pelo plenipotenciário John Methwen, 27 de dezembro de 1703, eliminou qualquer tentativa de instalação de indústrias, no Brasil. A Inglaterra se comprometia a favorecer o vinho português, que seria taxado abaixo do similar francês. Em troca, Portugal "abriu o próprio mercado, e o das colônias, de forma irreversível, às manufaturas inglesas”. Nesse mesmo século, começa o ciclo da mineração, aqui, aumentando o consumo de bens santuários, "criando possibilidades extraordinárias para os produtos ingleses". O ouro brasileiro foi enriquecer o tesouro inglês, cuja acumulação permitiu a esse país sustentar as guerras napoleônicas. Observando-se por outro prisma, a expoliação do Brasil "preparou a liquidação dos vínculos da Colônia com a Metrópole”. A influência inglesa foi maior e mais opressiva a partir de 1808, com a presença da Monarquia portuguesa, no Rio de Janeiro.

O assédio do capital e das manufaturas inglesas impossibilitou a industrialização do Brasil, eliminando a adoção do protecionismo, provocando desequilíbrios econômicos, conseqüentes dos acordos de 1810 e de 1827, pelos quais a proteção tarifária provocou uma baixa geral de preços das importações, aumentando a demanda e pressionando a balança de pagamentos e, logicamente, repercutindo na taxa de câmbio, com a depreciação da moeda interna.

Comparando o Brasil com o maior e mais poderoso país do Ocidente, que na mesma época, lutava contra os resíduos colonialistas e com uma população equivalente à nossa, os Estados Unidos da América, sem produção aurífera, no século XIX, já eram industrializados e nivelam-se às principais nações européias, "enquanto que o Brasil evoluía no sentido de transformar-se no século XX numa vasta região subdesenvolvida". Eliminando fatores superficiais comumente apontados, para explicar o nosso atraso, como clima, raça (inferior caldeamento de negro, Índio e português), ausência de rios que demandem ao interior, cadeias de montanhas paralelas ao litoral dificultando a penetração, o elemento essencial para o desenvolvimento norte-americano foi o protecionismo, adotado como "sistema geral de política econômica, em etapa já bem avançada do século XIX ”. Considere-se, ainda, que as condições sociais no grande país do Norte eram profundamente diversas das do Brasil, onde a 
economia era baseada em latifúndios que abrigavam os senhores de engenho e depois os barões do café, todos escravistas, ao passo que lá, o ruralismo edificou-se com pequenos agricultores e, nas cidades, predominavam grandes comerciantes. Alexandre Hamilton, um notável estadista, era o arauto da industrialização, advogando estímulos à indústria. No Brasil, Mauá era o obediente agente de Rothschild. Outro fator favorável aos Estados Unidos: a Inglaterra nunca permitiu a instalação de fornos para a produção de aço, mas incentivava a mineração do ferro, de que era dependente dos países do Báltico.

O regime de livre-câmbio, que permaneceu até 1844, como resultado de pressões externas, não deixou que se implantasse qualquer fábrica de porte médio, pelo menos, que pudesse competir com a indústria inglesa, que tornava as condições econômicas do Império precárias porque as importações suplantavam as exportações, primeiramente concedida aos ingleses, pelo Tratado de 1810, e agora, passados quarenta anos, estava estendida a todos os países. Em conseqüência, o produto nacional, para circular aqui dentro, sofria a concorrência estrangeira, como se verificava pelas aquisições feitas entre 1839-40 e 1843-44: têxteis 44,4\%, destes, 33,8\% eram tecidos de algodão; $21 \%$ de alimentos: farinha de trigo, bebidas e carnes; enquanto que calçados, chapéus e artefatos de couro entravam numa proporção de 3,7\%. Ao todo, as importações alcançavam 70\%, perfeitamente dispensáveis porque dispúnhamos de abundante matéria-prima, sendo que o Sul e o Centro-Oeste tinham condições de suprir todo o mercado nacional de carne, derivados e couro.

O Tratado de Tarifas com a Inglaterra expiraria em 1843, por isso aquele país pediu prorrogação, só conseguindo por um ano. Para pressionar o Brasil, elevou a taxa sobre o açúcar para 63 shillings, causando grandes prejuízos, pelo que representava aquele produto na pauta de exportação. Como resposta, o Ministro da Fazenda, Alves Branco, criou a tarifa, hoje conhecida por esse nome, elevando os direitos sobre 2919 artigos, desses, os tecidos e bebidas ficaram sujeitos a $50 \%$ e $605 \%$ de acréscimo e era exatamente o que mais importávamos. Os protestos do comércio importador, composto de estrangeiros, foram vigorosos, principalmente dos ingleses, os mais atingidos. Essa medida, de caráter fiscal, foi encarada como protecionista de uma indústria que, afinal, não tínhamos. Mas o Ministro visou, realmente, a estimular a criação de fábricas e a obrigar a Inglaterra a retroceder, quanto ao açúcar.

A medida Alves Branco concorreu para o surgimento de muitas indústrias, proporcionando uma série de vantagens ao sistema bancário, transportes, mineração, etc. Em 1850, contavam-se 72 estabelecimentos fabris produzindo cerveja, localizados: 40 na Província do Rio de Janeiro, 10 na Bahia, 4 em Pernambuco, 2 no Maranhão e os demais, em Minas Gerais, Rio Grande do Sul, São Paulo e Paraná. O mais importante desses centros manufatureiros localizava-se na Ponta da Areia, em Niterói, de propriedade do Barão de Mauá. Produziu tubos para encanamentos, navios, guindastes, caldeiras e pontes metálicas.

A pressão estrangeira não se fez esperar. O comércio importador conseguiu que uma comissão revisse a Tarifa Alves Branco. Em 1857, matérias-primas e maquinarias para a indústria sofreram redução para 15\% “ad valorem”, atingindo frontalmente a Ponta da Areia, ao reduzir também a taxação sobre ferragens, ferramentas, máquinas e armamento, levando-a à falência. Outro golpe contra a nossa industrialização viria em 1869, com a Tarifa Itaboraí, reduzindo os direitos sobre outras mercadorias, sugerindo uma revisão qüinqüenal das novas taxas. A Tarifa Rio Branco, de 1874, uniformizou em $40 \%$ as taxas das mercadorias, mas isentou de impostos a entrada de várias máquinas: retortas, alambiques, caldeiras, moinhos e outras. Em 1884, foi a vez das máquinas agrícolas, alegadamente para acabar com o contrabando no Sul e no Mato Grosso; isentas de qualquer ônus fiscal, juntamente com outras para a montagem de fábricas e oficinas. Em 1881, a Tarifa Saraiva variava os direitos segundo o valor da mercadoria, com a elevação progressiva da taxa de câmbio. Em 1887, foi promulgada a Tarifa Belisário Souza, tida como satisfatória à indústria. Considerada como protecionista, o que é negado por alguns que a consideram apenas como para proporcionar 
renda ao Tesouro. Explica-se, embora sumariamente, a nossa dependência à indústria estrangeira que, somada a ausência de medidas adequadas, com referência aos manufaturados nacionais, aniquilou a organização de um parque fabril que cobrisse todo território brasileiro, guardando suas características regionais.

Historicamente a luta do capitalismo internacional, inicialmente inglês e depois norteamericano, em relação ao Brasil, fora a de dificultar seu desenvolvimento industrial, a fim de conservar o mercado para seus produtos manufaturados de exportação.

\section{República}

A primeira fase da República, aquela limitada entre 69 e o Governo campos Sales, foi cheia de tumultos e indecisões. No início, dois fatos se salientam - a Constituição de 1891 e a reforma econômica de Rui Barbosa. A orientação do Ministro, que gozava de total confiança de Deodoro e dos principais vultos do novo regime, era imprimir um rumo diferente ao país; para isso, buscaria seus projetos "numa democracia do trabalho industrial". Esse desenvolvimento não seria só econômico, mas político também.

O advento da República não trouxe reformas significativas. A mudança do regime foi pacificamente aceita, embora o povo dela não tivesse participado; "O Império era, sem qualquer dúvida, a representação, no Brasil, de uma velha estrutura, que já não tinha condições de vigilância...”. O ideário republicano se fizera presente em todas as insurreições, desde a inconfidência aos Farrapos e daí até 89, quando, finalmente, se vitória, Movimento de letrados, que representava uma classe média fraca, jamais empolgou o todo da população e só atingiu sua proposta com o apoio da poderosa casta rural, atingida frontalmente pela Abolição, no ano anterior. A Monarquia se tornara um estorvo e apascentava a propaganda republicana, que anunciava uma nova realidade econômica e política.

A preocupação da República não foi outra senão aquela de alterar a estrutura do Estado, acabando com o Poder Moderador, com a vitaliciedade do Senado, com a centralização político-administrativa, representada pela nomeação dos governadores provinciais e, naturalmente, o desaparecimento da nobreza titulada.

As reformas anunciadas pelos republicanos não saíram dos campos das intenções e o novo regime permite uma relativa participação da classe média no poder e, desde o início, há uma luta provocada pela política tarifária e cambial, isto porque novas forças surgem e as antigas conquistam maior importância. Essa contenda de fundo econômico é devida à paulatina ascensão da classe dos comerciantes, dominada por estrangeiros, desde a abertura dos portos, de quem o sistema financeiro era dependente, em grande percentagem, porque a Nação se habituara com os produtos importados. Assim, o Império veio em declínio, agravando-se com as constantes viagens do Imperador à Europa e mais pela apreensão do terceiro reinado com um estrangeiro como imperador - o marido da Princesa Isabel, o Conde d’Eu. A aglutinação dos problemas crônicos com as questões social - escravidão; religiosa prisão de bispos; no Norte e militar culminaram com o 15 de Novembro.

A República foi o coroamento da luta pela descentralização, pela autenticidade da representação nacional, nas casas do Parlamento, ao abolir o fator renda, como condição para eleição. Por outro lado, a aspiração por uma educação abrangente a todas as classes sociais e o progresso econômico ficaram “dentro de uma visão apenas política” porque a República não trouxe um conteúdo social, apenas a propaganda catalisou os sentimentos com sua argumentação objetiva, através da imprensa e de "slogans", atingindo os ressentimentos contra o velho regime, contidos nos latifúndios, no clero e no Exército, esse com a concepção positivista, que encerrava a idéia de uma ditadura, na evasiva de um "governo dos melhores", significando vontades concentradas, isto é, o poder na mão de poucos. Vindo de encontro aos ideais republicanos, o Positivismo se fragmentou, no Brasil. 
/.../ faltou dimensão social à instauração da República, faltou também uma integração maior do povo na vida política: a obra constituinte foi tarefa de uma minoria dominante. $\mathrm{O}$ povo, na frase famosa de Aristides Lobo, assistira "bestificado" à implantação do novo regime. Não quer dizer que o povo estivesse sendo contrariado; estava simplesmente à margem das decisões.

Os militares no poder não tinham condições para executar as reformas que a Nação exigiu e que foram a bandeira dos republicanos. As divergências começaram ainda no Governo Provisório, entre Deodoro e Floriano. O afastamento do Rui Barbosa do ministério da fazenda é considerado como o alijamento da classe média dos destinos nacionais, comprovado pela convocação de antigos membros do regime monárquico, demonstrando, também, que não havia profunda incompatibilidade entre o novo e o velho sistema. A crise da República vai-se ampliando e alterando a estrutura econômica. Entre 1889 e 1892, ocorre o fenômeno conhecido como "encilhamento". As suas origens estão nas alterações do sistema de produção, baseada agora no trabalho livre; exigia um dispêndio de 50 mil contos de ris, num meio-circulante de 200.000 contos.

Nasce a concepção de que era necessário criar novas fontes de riqueza fora da agricultura. Surgem muitas sociedades anônimas e uma profusão de títulos nunca vistos, no Brasil. Alguns desses empreendimentos careciam de prática comercial, outras organizações tinham a preocupação de vender ações simplesmente a febris investidores que não faziam maiores indagações, o que logo redundava na perda total do capital empregado. Dentro em pouco, a confusão era geral e o governo chamou seus devedores - aqueles que tinham tomado empréstimo no banco oficial, para investir ações. Pouca coisa se salvou. O descrédito da sociedade anônima perduraria por muito tempo, prejudicando a economia do país.

A circulação, que era de 200.000 contos, em 1889, passa a 561.000, em 1891, e o capital das sociedades anônimas, de 800 mil assoma a 3 milhões de contos, no mesmo período. As partes não se deram conta de que a nossa economia, ainda colonial, não suportaria tamanho fluxo do capital, provocando inevitáveis desastres, responsáveis pelos surtos revolucionários de 1893 e 1895. Porém, o reflexo mais negativo do "encilhamento" foi sobre a taxa de câmbio, que caiu de $27 \%$, em 1889, para 16 e 10\%, em 1892, e para 6, em 1898 . O custo das utilidades sofre alta geral e a população é oprimida pelos preços, que além de tudo, tem seus salários pressionados, para compensar a depreciação cambial provocada pela imoderada expansão do crédito. O morador da cidade é o grande prejudicado, sem alternativa para o sumo de artigos importados.

As atividades industriais começam a ser atingidas pela política econômica. Determinados elementos, ligados à exportação, defendiam a manutenção daquela taxa de cambio. O problema monetário - a depreciação da moeda - causava inquietação a todos os setores de atividades: grupos de exportadores, a classe média em geral e os produtores agrícolas. O fazendeiro estava aliado ao capitalista estrangeiro, este recebia em ouro, no exterior, o que aqui produzia e exportava. Assim, era de seu interesse uma moeda estável. Ao contrário, os produtores nacionais de artigos de exportação defendiam a inflação e os importadores lutavam por uma estabilidade monetária, porque dependiam do estrangeiro, para aquisição de máquinas, de matérias-primas e artigos de consumo. Na última década do século, os saldos do comércio exterior entram em declínio, com um acréscimo único, em 1890/91, de 62 mil contos para 195 mil: em 1892, desce para 53.000 contos, com déficit em volta de 16.000 contos, em 1893.

Rui Barbosa, a quem cabe a culpa pelo "encilhamento", como Ministro da Fazenda do Governo Provisório, visou estabelecer um regime de circulação fiduciária que substituísse o papel-moeda do estado pelas emissões bancárias. As medidas introduzidas, além da reforma bancária e a alteração estrutural das sociedades anônimas, regulamentava as operações de crédito à produção, reformava a legislação hipotecária e, com a criação do Banco de Crédito 
Popular, estabelecia as bases de crédito real. Criaram-se os impostos de renda e o alfandegário Conrado em ouro, este, para desestimular as importações e incrementar a produção interna. Os terrenos baldios, as áreas incultas, o álcool, o fumo e o selo têm suas taxações elevadas. Houve especial preocupação em dinamizar o Ministério da Fazenda, criando-se o Montepio dos Funcionários Públicos e o tribunal de Contas. O porto de Santos foi construído e intensificou-se o combate ao contrabando. Todas essas transformações econômicasfinanceiras foram desfeitas com o afastamento de Rui Barbosa do Ministério da Fazenda, desaparecendo, assim, uma séria tentativa para o Brasil de moderna estrutura sócioeconômica.

Rui, de formação liberal, brilhante, de inigualável cultura, sem qualquer ligação com grupos econômicos e com um passado "limpo", depositário da confiança dos mandatários do novo regime, era convicto de que o desenvolvimento do Brasil deveria se basear numa democracia de trabalho industrial, conforme expressa o seu Relatório do Ministro da Fazenda. A sua atuação no Ministério republicano obedeceu à orientação do seu espírito aberto e inspirado em Alexander Hamilton, que propugnara reformas nos Estados Unidos, que levaram aquele país à condição de grande potência do século XX. Entretanto, Rui carregaria para o resto da vida a carga de responsabilidade pela desordem financeira que quase provoca um “crack” fatal o novo regime e nunca mais foi convidado para qualquer cargo público.

A implantação da República não trouxe mudança na estrutura econômica do país, porque continuamos com o nosso sistema agrário de produção baseado no latifúndio e uma economia monocultura, voltada para a exportação, pode negar que se verificaram transformações de certo vulto, facilitando determinadas modificações, que começaram a se fazer sentir.

Ao café, que já vinha ocupado posição vanguardeira na nossa economia, desde a segunda metade do século XIX, juntaram-se outras culturas, que tomaram grande expressão, no comércio com a Europa: o fumo, da Bahia: o mate, do Paraná e a pecuária, do Rio Grande do Sul, até então de âmbito interno. O café teve seu volume de exportação aumentado em $341 \%$ e os subiram $91 \% 90$.

Essa derradeira década toparia, ainda, com um problema que vinha tomando corpo desde meados de centúria - o Imperialismo, no qual a expressão industrial procura as áreas recém-egressas do colonialismo, ou ainda mergulhadas neste, permitindo o enriquecimento de uma burguesia que colaborará para o empobrecimento de uma burguesia que colaborará para o empobrecimento regional. Os centros de irradiação dessa forma de subdesenvolvimento estão na Europa, na América do Norte e na Ásia (Japão, pois o resto do continente é colonizado). Apesar de manter elevado os padrões da classe média, o imperialismo exerce controle sobre os sindicatos e as lideranças operárias, sendo inevitável, então, a corrupção desses grupos dirigentes das camadas inferiores. Ampliando seu poder, influiu dominantemente nas relações internacionais, com surtos bélicos, como o Hispano-Americano, em 1898; dos Bôeres, em 1899, que consolidou a presença inglesa no sul da África: dos Bóxeres, em 1900, movido pelas grandes potências européias, contra a China, para reformular o pacto colonial e alienar extensas áreas do solo nacional; em 1904, Rússia e Japão entram em conflito pela posse da Coréia e domínio do Pacífico. O continente europeu, fonte desses acontecimentos, não ficou isento de guerras, culminando com a conflagração de 1914/18, cujo cerne estava na Alsácia/Lorena, região carbonífera de jazidas de ferro entre as duas grandes potências, França e Alemanha, que a conquista, em 1870, após derrotar militarmente aquela.

A luta que os países industrializados moviam em todo o mundo pela conquista de mercados, de mercados, de matérias-primas ou procurando consolidar zonas de influência para expandir o capitalismo, incidia não só sobre os povos subdesenvolvidos, mas entre eles mesmos, como a já citada Guerra franco-Prussiana, de 1870. Nos países cuja economia se baseava na exportação de produtos primários, a economia tomou características próprias - 
maior produtividade, maior procura de manufaturados, cuja demanda é mais elevada quanto menor for a renda "per capita". Os artigos locais, até então artesanais, são substituídos por industrializados, diversificando a "composição da demanda global”. Os alimentos estavam nesse contexto.

O quadriênio Campos Sales, 1898/1902, que teve como Ministro da fazenda Joaquim Murtinho, herdou resíduos do "encilhamento" e das lutas armadas do período florianista. As dificuldades se localizavam no descrédito, perante às organizações financeiras internacionais, que nos negavam créditos. O novo governo propunha-se a uma programação deflacionária; para diminuir o déficit calculado para 1898, em 48.606 contos, lançou um empréstimo interno de $4 \%$ ouro e $5 \%$ papel e, ainda, a venda de navios da Armada para os Estados Unidos, em guerra com a Espanha. Murtinho lançou novos tributos, como o do solo e do imposto de consumo sobre mercadorias estrangeiras. O chefe do governo, pessoalmente, na Europa, tratou da dívida externa, conseguindo negociar o "funding-loan” com a Casa Rothschild, iniciado com Prudente de Moraes, Restabelecido o crédito internacional, a dívida reduziu-se com o pagamento do empréstimo feito no quadriênio anterior, de 1.120 .000 libras. A circulação fiduciária foi contida e encamparam-se estradas de ferro deficitárias.

As medidas impopulares visavam a "ganhar a batalha deflacionária", que atingiu o sistema bancário e mercantil, com muitas falências. Afinal, o orçamento fechou com saldo e com ouro acumulado, em Londres.

O governo Campos Sales decorreu dentro de uma crise mundial, considerada pelos historiadores como cíclica, que periodicamente ataca a economia dos países. Assim, essa seria responsável pelos males que nos afetavam, e não o regime republicano 84 .

O Brasil está totalmente inserido num quadro econômico, cujos reflexos mais evidentes se fazem atuantes na política aduaneira e os imensos problemas enfrentados pelos governos republicanos. O governo Rodrigues Alves não desfez o sistema cambial, dado as pressões dos credores estrangeiros, principalmente Rothschild, que tinha no Ministro da Fazenda Leopoldo Bulhões um defensor do livre-câmbio, considerando que alterar o sistema seria aumentar as dificuldades da população, já bem acentuadas. A indústria continuava asfixiada, seja pela ação do Ministro anterior Joaquim Murtinho, declaradamente antiindustrialista, seja pelo monopólio da indústria nacional, que encarecia seus produtos, não podendo competir com o similar estrangeiro, de melhor acabamento, e chegava ao consumidor mais barato. Na realidade, o que interessava era o aumento das rendas alfandegárias. Os problemas econômicos não estavam limitados ao Executivo e às repercussões políticas, aos protestos populares, à imprensa, mas no Parlamento as discussões eram constantes. De todos esses movimentos, surgiram grupos protecionistas e as entidades de classe, ainda incipientes, se uniram aos partidários do industrialismo, como o Clube de Engenharia, a estadistas e a políticos, que defendiam o protecionismo também para a agricultura, visando a acabar com a importação de alimentos e a organização de uma "indústria legítima”, aquela que utilizasse matéria-prima vegetal.

A industrialização empolgava a todos e, em 1905, no Congresso da Expansão Econômica, Vieira Souto defendia a "indústria artificial”, que não empregava matéria-prima nacional, advogando que, como país novo, não dispúnhamos de força suficiente para dispensar o produto básico estrangeiro, isto é, não éramos auto-suficientes e o importante seria ter indústrias, embora dependentes do exterior, caso contrário "ficávamos reduzidos à grande indústria de torrefação de café, com lenha e carvão nacional”. Tomaram parte nos debates membros do Centro Industrial do Brasil e do Centro Industrial do Brasil e do Centro Paulista de Fiação e Tecelagem, além de muitos líderes de classe. Ficou claro, também, que a reforma Murtinho já não satisfazia e estava entravando o desenvolvimento industrial e se fazia necessário uma revisão, criando-se duas comissões - uma oficial, com membros do Congresso, industriais e comerciantes, e outra patrocinada pela Associação Comercial do Rio 
de Janeiro. Ambas tinham um ponto em comum: o protecionismo. No Congresso, o deputado João Luís Alves antecipou-se às decisões das comissões que discutiam o problema e apresentou um projeto de lei que amparava a produção nacional por meio de tarifa protecionista. A primeira reação veio do corpo diplomático. Cada representante procurou defender o produto que seu país exportava para o Brasil. Outros protestos se fizeram ouvir de setores da própria indústria do fisco e da lavoura cafeeira. Os industriais defendiam que, pelo Projeto Luís Alves, se cobrasse um adicional em ouro e papel do manufaturado estrangeiro, o que provocou grandes protestos do comércio; o Ministro da Fazenda apôs-se porque o fisco seria privado do imposto de $1 \frac{1}{2} 2$ ouro, empregado nas obras do porto do Rio de Janeiro: a oposição dos cafeicultores se baseara em que os países prejudicados poderiam elevar as tarifas do café. Apesar dos protestos do comércio, o exercício de 1905 já contou com a cobrança de $50 \%$ nos impostos aduaneiros, sobre alguns produtos, em ouro, e $35 \%$, sobre outros artigos também importados. O projeto João Luís Alves ficou estacionário, na Câmara, e só em 1913 voltou-se a falar da necessidade de uma reforma tarifária.

A república consolidada, a dívida estancada, volta-se o Governo para as grandes obras públicas. O café e a borracha são os fortes sustentáculos da economia, ocupando aquele, 2/3 das nossas exportações. A superprodução de 22 milhões de sacas, em 1906, somadas a de 4 milhões estocadas de safras anteriores, provocaria, fatalmente, uma baixa na cotação internacional, sobre um consumo de 16 milhões de sacas. Os cafeicultores dos três principais estados produtores - Rio de Janeiro, São Paulo e Minas gerais - firmaram um acordo, em Taubaté, embora sem a participação da administração federal, pelo qual os preços seriam mantidos nos portos de embarque, ficando retido no país o excedente de consumo mundial, isto é, o que ultrapassasse 16 milhões de sacas. Para isso, era instituída uma taxa de 3 francosouro, por saca sobre o café exportado. O programa não teve o apoio do Presidente Rodrigues Alves que, entretanto, não interferiu para não atentar sobre o Federalismo, já que o acordo firmou-se entre estados-membros.

Nos mandatos seguintes, os efeitos benfazejos da política econômica de Campos Sales continuaram a se fazer sentir, permitindo notáveis realizações na administração pública, verificando-se a justeza do acordo de Taubaté, que realmente evitou a queda dos preços. Obras públicas modificavam a feição dos grandes centros urbanos; a classe empresarial se expandia, influindo no protecionismo e, como causa direta, o surgimento de muitas indústrias, mas a inteligência nacional tendia para uma elitismo em que os títulos nobiliárquicos eram substituídos pelos diplomas de doutor, procurando seus detentores a sombra do Estado, como faziam os nobres à sua época. O importante era que as finanças estavam equilibradas e o tesouro saldava plenamente os compromissos. Afora os levantes dos couraçados "Minas Gerais" e "São Paulo" - a chamada Revolução da Chibata -, a intervenção nos estados, revolta de jagunços e o Contestado, a situação era d calma, pois esses movimentos careciam de amplitude.

Novos empréstimos foram feitos no exterior, entre 1913/1914, para sustentar o preço do café e, nesse mesmo ano fiscal, as exportações baixaram a 750 mil contos, obrigando uma queda na taxa cambial de 15 para 10. Esses fatos provocaram déficits orçamentários com a solução imediatista da emissão do papel-moeda, após fracassarem as tentativas de empréstimo no exterior. Entretanto, a Primeira Guerra Mundial fora benéfica às nossas finanças e forçou a organização de parques fabris, para suprir o mercado interno carente daqueles produtos que a guerra nos tolhera. Assim, aquela conflagração, sob outro aspecto, também fora benéfica ao comprar materiais brasileiros, quaisquer que lhes fossem oferecidos. As taxas cambiais estavam firmes, embora o meio-circulante continuasse elevado.

Com o término do conflito, a economia européia se reorganizou, com reflexões nas nossas exportações, afetando o câmbio e o café, para o qual os produtores paulistas pleiteavam uma intervenção federal, face à queda da exportação do produto, em 1920. O 
governo adquiriu parte da safra, créditos de 50 milhões de dólares, para combate às secas no Nordeste e de 25 milhões, para melhoria da rede ferroviária, inclusive a eletrificação da Central do Brasil, foram conseguidos no exterior. O Lóide Brasileiro transformou-se em sociedade anônima e foi criada a Universidade do Rio de Janeiro.

A situação econômica, porém, continuava difícil, principalmente pela queda da exportação do café e pelos compromissos a que nos obrigamos, desde o final da guerra. No último quadriênio da república Velha, teve enorme ênfase o desenvolvimento rodoviário, os reflexos financeiros permitirem o equilíbrio orçamentário e o aumento das reservas-ouro, mas a crise mundial de 1929, provocada pela queda da Bolsa de Nova Iorque, nos colheria em cheio para conter a produção, ou substituir as plantações, o que exigia vultosos capitais para cobrir as perdas. A depressão teria como desfecho a Revolução de 1930, iniciando a chamada Segunda República.

No campo econômico, a primeira providência foi de ordem administrativa, para eliminar o déficit de 1.3000 .000 contos de réis, enquanto que a dívida externa foi lançada mão da reserva-ouro da Caixa de Estabilização e do Banco do Brasil, conseguindo, assim, manter em dia os pagamentos, negociando um "funding" de 20 milhões de libras. Outras medidas econômicas foram tomadas pelo regime: reajustamento das dívidas agrícolas, destruição de excedentes de café estocados, permitindo, desta forma, ao agricultor, continuar produzindo e manter os preços estáveis.

Em 1933, a economia já dava sinais de recuperação, com a grande colheita de café, e a safra algodoeira se desenvolvia grandemente. Com o aumento do mercado interno, a indústria começa a sair da crise, com o aumento de $50 \%$, até 1937 , a renda nacional cresceu em $20 \%$. O Estado Novo, instituído em 10 de novembro de 1937, pela sua Carta, criou o Conselho de Economia Nacional, formado por representantes da produção e empregados, por membros de sindicatos e associações profissionais, presidido por um ministro de Estado.

$\mathrm{Na} 2^{\mathrm{a}}$. Guerra Mundial, os preços das exportações subiram bastante, superando os preços internos. Em conseqüência, houve uma crescente e incontida inflação. O resultado direto da guerra foi a substituição do valor da produção agrícola pelo da produção industrial, isto porque a carência de industrializados importados nos forçou a criar um parque fabril, permitindo-nos o fornecimento de bens de produção, em vez de bens de consumo.

Nas décadas de 40 e 50, os manufaturados ainda se caracterizavam pela indústria leve de transformação, com predomínio de alimentos e tecidos e, em plena expansão, os artigos de consumo imediato, de boa qualidade, satisfazendo plenamente o consumidor. Já que era bem volumosa a produção siderúrgica, quadruplicando a produção de aço, com o início das atividades de Volta Redonda, em 1941, pesando, positivamente, na evolução do nosso desenvolvimento. A expansão econômica permite assimilar, em 1950, 92.350 estabelecimentos fabris, empregando 1.279.184 trabalhadores, com um capital aplicado de mais de 53 milhões de cruzeiros, produzindo cerca de 120 bilhões. Ainda nesse mesmo ano, a Guerra da Coréia elevou as cotações das matérias-primas no mercado mundial e isso nos favoreceu, mas sob certos aspectos nos foi prejudicial, porque os produtos primários d que éramos dependentes do estrangeiro são também afetados pela alta e passam a ser racionados.

O Governo Vargas cria instrumentos como a Assessoria Econômica, órgão da Presidência da República, para facilitar o sistema econômico. Um dos seus feitos foi a criação da Petrobras, estabelecendo, com a Lei 2004/53 e o decreto número 35.308/54, o monopólio estatal para os carburantes. Por essa assessoria, nasceu o Plano Nacional do Carvão, coordenado por uma Superintendência; o Fundo Federal de Eletrificação dirigida à Eletrobras. Foi ainda na década de 50 que tem início a indústria nacional de automotores; são criados o BNDE (hoje Banco do Desenvolvimento Econômico Nacional e Social) e o Banco do Nordeste; a Usina Siderúrgica Nacional, em Volta Redonda, é ampliada e no rio São Francisco, inaugura-se a Hidrelétrica, responsável atualmente pelo grande surto 
desenvolvimentista do Nordeste. O capital estrangeiro recebe atenções especiais, racionalizando-se sua entrada e saída. Nesse setor, a extinção da Missão Abbink foi um retrocesso nas relações econômicas com os Estados Unidos. Essa Missão Mista BrasilEstados Unidos, que se propunha a um amplo programa, de desenvolvimento econômico, mas, com a ascensão dos Republicanos ao poder, o Presidente Eisenhower dissolveu a Comissão.

O processo de industrialização se acelerava, começando a dominar nossa economia, secularmente agrícola e sofrendo, ainda, reflexos das importações. É notável que a indústria começa a receber uma percentagem bem maior de inversões do que os demais setores, expandindo-se, permitindo acumulação de capital que passaria de um exercício para outro. Em conseqüência, o comércio exterior diversifica-se - as importações de gêneros alimentícios e manufaturados são substituídos por combustíveis, máquinas e equipamentos.

A década de 60 inicia com duas características: o fim do Programa de Metas, que dominara na anterior, e o processo de diversificação industrial, dando ao país um perfil de economia moderna. É nessa década que se acentua a intervenção do Estado na economia privada, num processo abrangente e interminável, com a criação de novos de novos organismos, surgindo poderosas empresas paraestatais "sem qualquer esquema preconcebido".

\section{Conclusão}

Qualquer estudo que se faça da economia brasileira, têm que ser levados em consideração fatores dominantes como a tecnologia, o capital e os recursos humanos. Começando pelo capital, tivemos sempre que capta-lo no exterior, tendo sido fundamental para o nosso desenvolvimento. Inegavelmente, os recursos naturais de que dispomos são enormes, mas para a sua exploração, o concurso de empresas estrangeiras 'fundamental, isoladas ou ligadas a grupos nacionais, repartindo-se os interesses, de nossa parte, evitando-se a saída excessiva de divisas - royalities -, visando à assistência técnica e ao desenvolvimento tecnológico, mas agindo de forma a não prejudicar a valorização profissional e os técnicos brasileiros. Uma segunda consideração é não abandonar a exploração de recursos naturais que não interessam ao estrangeiro, mas são de utilidade para o país.

A tecnologia é essencial para o Brasil, mas deve ser examinada na maneira como ela entra, se é ultrapassada, como será empregada aqui, quais as inovações que introduzirá, se pode ser implantada rapidamente ou adquirida no mercado mundial (comprada). Esses critérios influirão no andamento da industrialização de um país novo como o Brasil, onde qualquer empreendimento é uma inovação, dependente de técnicas e da propagação dessa inovação. Essas novas empresas criarão infra-estrutura indispensável, pagando alto custo pela mesma e tem sido responsável pelo surgimento de monopólios ou grupos de expressiva força econômica. Naturalmente que o interesse dessas empresas não coincidem com os objetivos nacionais - crescimento e desenvolvimento -, colimados ao bem-estar da população. Daí, o especial cuidado em aceitar o aspirado progresso.

Foi, pois, o desejo de um desenvolvimento que abrangesse todas as camadas sociais que moveu o estatismo no Brasil e não por razões ideológicas (socialismo). A interferência do Estado se justifica, assim, plenamente, se considerarmos que sua proposta é desenvolver nossas potencialidades.

Por derradeiro, ousaria afirmar que a temática ora em apreço, até mesmo pelas suas características doutrinárias e conjunturais da época envolvida por este estudo, em si não se finda, ensejando, em conseqüência, discussões e contribuições acadêmicas, sempre salutares e bem-vindas em nosso convívio. 


\section{Referências}

AFFONSO, Almiro. Grupos de pressão e suas repercussões na economia nacional. São Paulo: APEC, 1970.

AVELAR, Hélio de Alcântara. História administrativa econômica do Brasil. Rio de Janeiro: FENAME, 1970.

BARBOSA, Waldemar de Almeida. A Câmara dos Deputados como fator de unidade nacional. Rio de Janeiro: José Olímpio, 1977.

COSTA, Bolívar. O drama da classe média. Rio de Janeiro: Paz e Terra, 1974.

DAEMON, Dalton. Reflexões a economia brasileira. Rio de Janeiro: Biblioteca do Exército, 1982. (Col. Gen. Benício, pub. 523, vol. 204).

DOBB, Maurice. A evolução do capitalismo. 7. ed./Studies in the Development of Capitalism/Trad. Manuel do Rego Braga. Rio de Janeiro: Zahar, 1980.

FURTADO, Celso. O Brasil pós-“milagre”. 6. ed. Rio de Janeiro: Paz e Terra, 1981.

GALBRAITH, John Kenneth. A era da incerteza.Trad. F.R. Nickelsen Pellegrini. São Paulo: Pioneira, 1980.

GALBRAITH, John Kenneth. O novo estado industrial. Trad. Leônidas Contijo de Carvalho. São Paulo: Pioneira, 1977.

GAMA, Aníbal. Libertação do Brasil do jugo lusitano. Rio de Janeiro: Biblioteca Militar, 1946.

GOMES, Carlos de Oliveira. A solidão segundo Solano Lopes. São Paulo: Círculo do Livro, 1982.

GUIMARÃES, Alberto Passos. Quatro séculos de latifúndio. 3. ed. Rio de Janeiro: Paz e Terra, 1968.

KERSTENETZKY, Isaac. A mudança do papel do Governo na economia. In: Painéis internacionais sobre desenvolvimento socioeconômico. Rio de Janeiro: APEC/BNDE, 1974.

LIMA, Hélio da Silva. Crônica de intervalos. Rio de Janeiro: AAFBB, 1980. LOBO, Roberto Haddock. História econômica geral e do Brasil. 4. ed. São Paulo: Atlas, 1973.

MAGALHÃES, Francisco de B. B. de. História econômica. 7. ed. São Paulo: Sugestões Literárias, 1981.

MATHIAS, Herculano Gomes et alii. História do Brasil. Rio de Janeiro: Bloch, 1976. 
MATTOS, Carlos Meira. A geopolítica e as projeções do poder. Rio de Janeiro: Biblioteca do Exército, 1977.

PEREIRA, Luiz Carlos Bresser. Empresários e administradores no Brasil. São Paulo: Brasiliense, 1974.

SALDANHA, Nelson. O pensamento político do Brasil. Rio de Janeiro: Forense, 1979.

SMITH, Adam. Riqueza das Nações._Trad. Teodora Cardoso e Luís Cristóvão de Aguiar. Lisboa: Fundação Caloustre Gulbekian, 1981.

SODRÉ, Nelson Werneck. Formação histórica do Brasil. 10. ed. Rio de Janeiro: Civilização Brasileira, 1979.

VIDOR, George. O Brasil nasceu endividado, mas sempre pagou aos credores. O Globo, Rio de Janeiro, 24 out. 1982. Cãs. Ec., p. 40, c.1-2-3-4-5-6.

Informações bibliográficas:

Conforme a NBR 6023:2002 da Associação Brasileira de Normas Técnicas (ABNT), este texto científico publicado em periódico eletrônico deve ser citado da seguinte forma:

SOUZA, A. R. . Aspectos Econômicos do Brasil Independente. Cadernos UniFOA, Volta Redonda, ano 1, n. 2, nov. 2006. Disponível em:

$<$ http://www.unifoa.edu.br/pesquisa/caderno/edicao/02/43.pdf> 